\title{
Alternative Energy Sources on Digital Comic Media
}

\section{Komang Alit Darma Adnyani ${ }^{*}$, I Made Citra Wibawa², I Gede Margunayasa ${ }^{3}$}

1,2,3 Prodi Pendidikan Guru Sekolah Dasar, Jurusan Pendidikan Dasar, FIP Universitas Pendidikan Ganesha, Singaraja, Indonesia

\author{
A R T I C L E I N F O \\ Article history: \\ 12 December 2020 \\ Received in revised form \\ 03 January 2021 \\ Accepted 20 January \\ 2021 \\ Available online 25 \\ February 2021 \\ Kata Kunci: \\ Komik Digital, Sumber \\ Energi Alternatif \\ Keywords: \\ Digital Comic, Alternative \\ Energy Sources
}

\begin{abstract}
A B S T R A K
Ketersediaan media pembelajaran inovatif di sekolah masih terbatas, khususnya pada muatan ilmu pengetahuan alam siswa kelas IV SD. Penelitian ini bertujuan untuk mengembangkan media komik digital pada topik sumber energi alternatif siswa kelas IV SD. Penelitian ini menerapkan jenis penelitian pengembangan (R\&D) menggunakan model pengembangan ADDIE dengan tahapan sebagai berikut: analyze (analisis), design (perancangan), development (pengembangan), implementation (implementasi), dan evaluation (evaluasi). Subjek penelitian ini adalah 2 orang dosen sebagai ahli media, 2 orang dosen sebagai ahli materi, 2 orang guru sebagai praktisi, dan 5 siswa kelas IV SD, sedangkan objek dalam penelitian ini adalah validitas media komik digital yang dikembangkan. Metode pengumpulan data yang digunakan adalah metode kuesioner dengan memberikan lembar penilaian kepada ahli, praktisi, dan siswa. Instrumen yang digunakan untuk mengukur tingkat validitas media komik digital adalah rating scale berupa lembar penilaian media komik digital dari ahli, praktisi, dan siswa. Data yang diperoleh kemudian dianalisis dengan menggunakan rumus persentase untuk mengetahui validitas media komik digital. Nilai rata-rata skor persentase dari ahli materi sebesar 96\% ahli media sebesar 97\%, praktisi
\end{abstract} sebesar 87\%, dan siswa kelas IV SD sebesar 94\% dengan kualifikasi sangat baik. Berdasarkan hasil tersebut media komik digital yang dikembangkan pada topik sumber energi alternatif dinyatakan valid dan layak digunakan dalam pembelajaran di kelas IV SD.

\begin{abstract}
A B S T R A C T
The availability of innovative learning media in schools is still limited, especially in the subject of the natural sciences of fourth-grade elementary school. This research aimed at developing digital comic media on the topic of alternative energy sources for fourth-grade elementary school students. This study applied the research and development (R\&D) method using the ADDIE development model with the following stages: analyze, design, development, implementation, and evaluation. The subjects of this study were two lecturers as media experts, two lecturers as material experts, two teachers as practitioners, and five fourth-grade elementary school students, while the object in this study was the developed validity of the digital comic media. The data collection method was a questionnaire method by providing assessment sheets to the subjects of the study. The instrument used to measure the validity level of digital comic media was a rating scale in the form of assessment sheets compiled from experts, practitioners, and students. The data obtained were then analyzed using a percentage formula to determine the validity of digital comic media. The average percentage scores are $96 \%$ by material experts, $97 \%$ by media experts, $87 \%$ by practitioners, and $94 \%$ by fourth-grade elementary school students, with very good classifications. Based on the results, digital comic media developed on the topic of alternative energy sources is declared valid and suitable to apply in learning in fourth-grade elementary school.
\end{abstract}

\section{Introduction}

The covid-19 virus in Indonesia is currently having a major impact on the entire community. The impact occurs in various fields, including the education sector. As educators around the world face unprecedented challenges, physical interaction-based academic activities are limited during pandemics (Srivastava et al., 2021). The Ministry of Education and Culture of Indonesia issued Circular Letter Number 4 of 2020 concerning the Implementation of Education Policy in the Emergency Period of the Coronavirus Disease (Covid-19). It explains the learning process from home through distance learning to provide a meaningful learning experience for students (Ahmed et al., 2021; Dewi, 2020). Online learning is a new way of learning that uses internet networks with accessibility, connectivity, flexibility, and the ability to generate various types of learning interactions (Rigianti, 2020; Sadikin \& Hamidah, 2020). Online learning is very different from the usual learning, which emphasizes the thoroughness and

Copyright (C) Universitas Pendidikan Ganesha. All rights reserved. 
foresight of students in receiving and processing the information presented online (Putria et al., 2020). Despite this challenging situation, most academic institutions in the world have been tried to ensure the continuity of the learning process that has shifted from traditional to modern one, where students and teachers interact with each other using various types of technological tools and techniques as the introduction of learning (Qazi et al., 2021; Rafique et al., 2021). In this case, a teacher is not only required to master the learning material but also must be able to create and utilize learning media.

Learning media is one of the intermediaries used by the teachers to make it easier for students to understand a learning material. The use of media in learning is intended as a learning resource and a tool that can provide an overview to students to motivate learning, clarify and simplify complex and abstract concepts to become simpler and easier to understand (Baharun, 2016; Hilmi 2017). Technology-based learning media is very necessary given because media in digital form can be used as a substitute teacher and can attract the attention of students to participate in learning (Widjayanti et al., 2018).

In reality, the use of media in learning is still not optimal. This is because online learning is different from face-to-face learning. The most visible difference is the lack of understanding of students in learning material due to the teacher's unpreparedness for online media (Daheri et al., 2020; Harahap et al., 2021). This is also supported by the interview results with the fourth-grade teachers of Elementary School Cluster V Buleleng District of Academic Year 2020/2021, that learning materials and medias provided by teachers are still limited, online learning in elementary schools only rely on WhatsApp and student books. Therefore, students easily get bored and do not understand the learning materials, which one of them is the natural science subject on the topic of alternative energy sources. Solutions are needed to be found for this problem, one of the solutions is the development of learning media in digital form, which attracts students' attention, so that students do not get bored easily while participating in learning. One of the media solutions that can be developed is digital comic media.

Digital comics are lined images in a deliberate sequence, intended to convey information or produce an aesthetic response from readers (Ratnasari \& Ginanjar, 2020). Comics are also simple, clear, and easy to understand. Comics have their charm in the form of a combination of stories and images so they are easy to understand and do not seem patronizing so that comics can be used as learning media (Ramadhan \& Rasuardie, 2020). The use of digital comics in the learning process will provide positive responses from students. Students will be enthusiastic while participating in learning by using digital comics and have a pleasant learning atmosphere. The information presented is easier to understand because it's attractive and it combines various elements of images, narration, and animation (Hidayah, 2017; Wahyudin et al., 2020). The effectiveness of media digital comics is also supported by some previous researchers, the development of digital comic media is suitable to use in learning because it has visual element to attract the attention of students (Mulenga, 2020), the development of digital comic media is effective as an innovative medium because the characters in comics can attract students' attention (Sukmanasa et al., 2017), validation results of digital comic media is valid and able to improve students' understanding of natural resources topic (Rohmanurmeta \& Dewi, 2019), illustration images and comic characters can provide information to students in an interesting and fun way (Rachman \& Widowati, 2018), and the use of digital comic in online learning can increase the success of learning process and helps to develop positive behavior of students (Illhan et al., 2021).

Based on the previous studies, digital comics have been developed but they also have several weaknesses, such as the comic characters are not original, the media comic packaged in book form, and the background used is still rigid and not interactive yet. The digital comic media developed in this study has some differences compared to similar media, such as using the topic of alternative energy sources for fourth-grade elementary school students, the development of comic media is in video form, the characters used also have never been encountered before, and the background used can move so that students are interested in watching the entire comics. Then, through this digital comic media, these students are expected to be motivated to learn the Science subject independently and enjoyably.

\section{Method}

This study applied the research and development (R\&D) method, using the ADDIE development model with the following stages: (1) Analyze, (2) Design, (3) Development, (4) Implementation, and (5) Evaluation (Tegeh \& Kirna, 2013). However, the Implementation and Evaluation stages were not implemented due to limited time, resources, and financial. The research procedure begins with the analysis stage which consists of four activities, such as: (1) needs analysis, which includes interviewing and distributing questionnaires to teachers, (2) student characteristics analysis to determine the condition of students related to the media being developed, (3) curriculum analysis, to analyze core competencies (KI), basic competencies (KD), learning objectives, and subject matter in student books, and 
(4) media analysis, to determine the criteria for good media to be used as guidelines in developing the developed media. The design stage is carried out in several stages, including (1) determining the topic of the material being developed, (2) making a digital comic storyline design, (3) consulting the digital comic media design to the supervisor, and (4) making improvements to the media design from the guidance results. Further trials were carried out on the media that had been developed through assessments by two lecturers as material experts, two lecturers as media experts, two teachers as practitioners, and five fourth-grade elementary students. After the media has been assessed, the data obtained is then analyzed and revised on the digital comic media based on the assessment data from material experts, media experts, practitioners, and students.

The subjects of this study were two lecturers as media experts, two lecturers as material experts, two teachers as practitioners, and five fourth-grade elementary school students, while the object in this study was the developed validity of the digital comic media. The type of data in this study was divided into two types. First, qualitative data in the form of words derived from the input and advice from the experts. Second, quantitative data in the form of figures obtained by assessment score of the test experts. The data collection method in this study used a questionnaire method, while the research instrument used was a rating scale in the form of a digital comic media assessment sheet. The media validity sheet instrument covers seven aspects, such as material/content, language/communication, presentation, sound and text, visuals, characterization, and overall appearance aspect. The grids of digital comic media validation sheets are presented in Table 1, Table 2, Table 3, and Table 4.

Table 1. Material Expert Validation Sheets Grid

\begin{tabular}{|c|c|c|c|c|}
\hline No. & Aspect & Dimension & $\begin{array}{c}\text { Item } \\
\text { Number }\end{array}$ & $\begin{array}{c}\text { Total of } \\
\text { Item }\end{array}$ \\
\hline \multirow[t]{3}{*}{1} & Material/ content & $\begin{array}{l}\text { Completeness and clarity in conveying } \\
\text { identity }\end{array}$ & 1,2 & 2 \\
\hline & & Clear delivery of learning objectives & 3 & 1 \\
\hline & & Clear delivery of material & $4,5,6,7,8$ & 5 \\
\hline \multirow[t]{2}{*}{2} & Language/ & The suitability of language & $9,10,11$ & 3 \\
\hline & Communication & $\begin{array}{l}\text { Use common phrases that are easy for } \\
\text { students to understand }\end{array}$ & 12 & 1 \\
\hline \multirow[t]{3}{*}{3} & Presentation & Coherence & 13,14 & 2 \\
\hline & & Cohesiveness & 15 & 1 \\
\hline & & Total & & 15 \\
\hline
\end{tabular}

Table 2. Media Expert Validation Sheets Grid

\begin{tabular}{|c|c|c|c|c|}
\hline No. & Aspect & Dimension & $\begin{array}{c}\text { Item } \\
\text { Number }\end{array}$ & $\begin{array}{l}\text { Total of } \\
\text { Item }\end{array}$ \\
\hline \multirow[t]{2}{*}{1} & Sound and text & Text is presented clearly & 1,2 & 2 \\
\hline & & Sound is presented clearly & 3,4 & 2 \\
\hline \multirow[t]{3}{*}{2} & Visual & Illustrations are presented clearly & 5,6 & 2 \\
\hline & & Interesting background display & 7,8 & 2 \\
\hline & & The combination in the use of colors & 9,10 & 2 \\
\hline \multirow[t]{2}{*}{3} & Characterization & Selection of characters & 11,12 & 2 \\
\hline & & The attractiveness of characters & 14 & 1 \\
\hline \multirow[t]{2}{*}{4} & Overall Appearance & Overall appearance integration & 14,15 & 2 \\
\hline & & Total & & 15 \\
\hline
\end{tabular}

Table 3. Practitioner Validation Sheets Grid

\begin{tabular}{llllc}
\hline \multirow{2}{*}{ No. } & \multicolumn{1}{c}{ Aspect } & \multicolumn{1}{c}{ Dimension } & \multicolumn{1}{c}{$\begin{array}{c}\text { Item } \\
\text { Number }\end{array}$} & $\begin{array}{c}\text { Total of } \\
\text { Item }\end{array}$ \\
\hline 1 & Material/ content & $\begin{array}{l}\text { Completeness and clarity in conveying } \\
\text { identity }\end{array}$ & 1,2 & 2 \\
& & & & 1 \\
& & Clear delivery of learning objectives & 3 & 5 \\
2 & Language/ & Clear delivery of material & $4,5,6,7,8$, & 3 \\
& Communication & The suitability of language & $9,10,11$ & 1
\end{tabular}




\begin{tabular}{|c|c|c|c|c|}
\hline No. & Aspect & Dimension & $\begin{array}{c}\text { Item } \\
\text { Number }\end{array}$ & $\begin{array}{c}\text { Total of } \\
\text { Item }\end{array}$ \\
\hline & & students to understand & & \\
\hline \multirow[t]{2}{*}{3} & Presentation & Coherence & 13,14 & 2 \\
\hline & & Cohesiveness & 15 & 1 \\
\hline \multirow[t]{2}{*}{4} & Sound and text & Text is presented clearly & 16,17 & 2 \\
\hline & & Sound is presented clearly & 18,19 & 2 \\
\hline \multirow[t]{3}{*}{5} & Visual & Illustrations are presented clearly & 20,21 & 2 \\
\hline & & Interesting background display & 22,23 & 2 \\
\hline & & The combination in the use of colors & 24,25 & 2 \\
\hline \multirow[t]{2}{*}{6} & Characterization & Selection of character & 26,27 & 2 \\
\hline & & The attractiveness of character & 28 & 1 \\
\hline \multirow[t]{2}{*}{7} & Overall Appearance & Overall appearance integration & 29,30 & 2 \\
\hline & & Total & & 30 \\
\hline
\end{tabular}

Table 4. Student Validation Sheets Grid

\begin{tabular}{|c|c|c|c|c|}
\hline No. & Aspect & Dimension & $\begin{array}{c}\text { Item } \\
\text { Number }\end{array}$ & $\begin{array}{c}\text { Total of } \\
\text { Item }\end{array}$ \\
\hline \multirow[t]{2}{*}{1} & Material/ Content & Clear delivery of learning objectives & 1 & 1 \\
\hline & & Clear delivery of material & 2 & 1 \\
\hline 2 & $\begin{array}{l}\text { Language/ } \\
\text { Communication }\end{array}$ & $\begin{array}{l}\text { Use common phrases that are easy for } \\
\text { students to understand }\end{array}$ & 3,4 & 2 \\
\hline 3 & Presentation & $\begin{array}{l}\text { Attractiveness in the presentation of the } \\
\text { material }\end{array}$ & 5,6 & 2 \\
\hline \multirow[t]{2}{*}{4} & Sound and Text & Text is presented clearly & 7,8 & 2 \\
\hline & & Sound is presented clearly & 9,10 & 2 \\
\hline \multirow[t]{2}{*}{5} & Visual & Images are presented clearly & 11 & 1 \\
\hline & & Interesting background display & 12,13 & 2 \\
\hline 6 & Characterization & The attractiveness of character & 14 & 1 \\
\hline \multirow[t]{2}{*}{7} & Overall Appearance & Overall appearance integration & 15 & 1 \\
\hline & & Total & & 15 \\
\hline
\end{tabular}

The method and data analysis techniques used in this research are descriptive qualitative analysis method and quantitative analysis. The qualitative descriptive analysis method is a method of processing data in the form of sentences or grouping an object, while the quantitative descriptive analysis method is a way of processing data in the form of numbers or percentages regarding the object under study. The qualitative descriptive analysis method in this study is used to present suggestions and comments from each expert, practitioner, and student related to the media that has been developed, while the quantitative descriptive analysis method in this study is used to describe the percentage score of each expert, practitioners, and students related to media that have been developed through the provision of digital comic media assessment sheets. The data is then converted with five scale conversion guidelines to determine the qualifications of the media validity developed as in Table 5 . The five scale conversion guidelines in Table 5 in this study determine the minimum feasibility of "fair". If the results of the final research are "fair", then the digital comic is deemed fit for use as a learning medium on the topic of alternative energy sources for fourth-grade elementary school students.

Table 5. Conversion of Achievement Rate with a Scale of Five

\begin{tabular}{cc}
\hline Achievement Rate (\%) & Classification/Predicate \\
\hline $90-100$ & Very Good \\
$75-89$ & Good \\
$65-74$ & Fair \\
$55-64$ & Poor \\
$0-54$ & Very Poor \\
\hline
\end{tabular}

\section{Result and Discussion}




\section{Results}

The analysis was carried out in several stages, such as needs analysis, curriculum analysis, student characteristic analysis, and media analysis. The needs analysis was carried out on November $10^{\text {th }}$ $11^{\text {th }}, 2020$ by distributing questionnaires and interviews to fourth-grade teachers at Elementary School Cluster V, Buleleng District. Based on the results of the questionnaire, it was found that (1) $85.7 \%$ of teachers stated that the scope of material in the available science textbooks was limited, (2) $85.7 \%$ of teachers felt that the appearance of teaching material books was less attractive, (3) 100\% of teachers stated that learning medias in school were still limited and they had never used digital comic as the media of learning process, and (4) $86 \%$ of teachers stated that science material needs to be developed or packaged into digital comic media. Based on the results of interviews conducted with fourth-grade teachers at Primary School Cluster V, Buleleng District, it was found that the learning that usually given to students was only based on theme books, image media, and learning videos which were accessed from the YouTube application only. Judging from the lack of innovation in learning media, especially on the topic of alternative energy sources, students will not deepen the learning material provided and easily feel bored with the appearance of textbooks. Curriculum analysis is carried out by analyzing basic competencies (KD) and indicators contained in teacher books and student books that can be used as guidelines in developing media. The analyzed basic competence and indicators are Theme 9 in the second semester regarding alternative energy sources. Analysis of student characteristics is used to determine the characteristics of fourth-grade primary school students who will use the developed media. Media analysis is carried out to obtain information about the quality of media that is good for use. There are seven aspects of the criteria used in the development of this media, including material or content aspects which include completeness in conveying identity, conveying learning objectives, and delivering material. Aspects of language or communication include the appropriateness of using language rules and using language that is easy for students to understand. Presentation aspects include coherence and cohesiveness in presentation. Aspects of sound and text that include text and sound are presented displayed. Visual aspects including illustrations presented, attractive background display, and combination in the use of colors. As well as characterization aspects which include character selection and attractiveness of characters. The design stage is carried out by designing the media to be developed. The design of this digital comic learning media begins with compiling a storyline, then continues with creating characters, backgrounds, and comic text balloons in digital form according to the compiled storyline. Making character characters begins with manual drawing using a pencil, then the characters are converted into digital form, then digitally creating the background and comic text balloons using the same application, such as the Photoshop CS 6 application and also assisted by the Comic Life 3 application. After finishing creating the characters, background, along with comic text balloons, the next step is to arrange the characters with text balloons according to the background and storyline that has been planned into a video with a 16: 9 ratio using the Adobe Premiere CS 6 application, then prepare a sound recording or dubbing according to the comic conversation of each character using the Adobe Audition application. After the design is finished, the design is then consulted with the supervisors. The design process for digital comic media can be seen in Table 6 .

Table 6. Digital Comic Media Design

\begin{tabular}{ll}
\hline \multicolumn{1}{c}{ Concept Design } & \multicolumn{1}{c}{ Application } \\
The process of creating the & The manual image is then \\
character & The character of Kak Alit
\end{tabular}




\begin{tabular}{ll}
\multicolumn{1}{c}{ Concept Design } & \multicolumn{1}{c}{ Application } \\
\hline $\begin{array}{l}\text { Background creation } \\
\text { process. }\end{array}$ & Photoshop \\
\hline $\begin{array}{l}\text { Background and character } \\
\text { combining process. }\end{array}$ & Comic life 3 \\
\hline $\begin{array}{l}\text { The process of designing a } \\
\text { comic into a video. }\end{array}$ & Adobe premier \\
\hline
\end{tabular}

The process of dubbing and Adobe audition noise elimination.
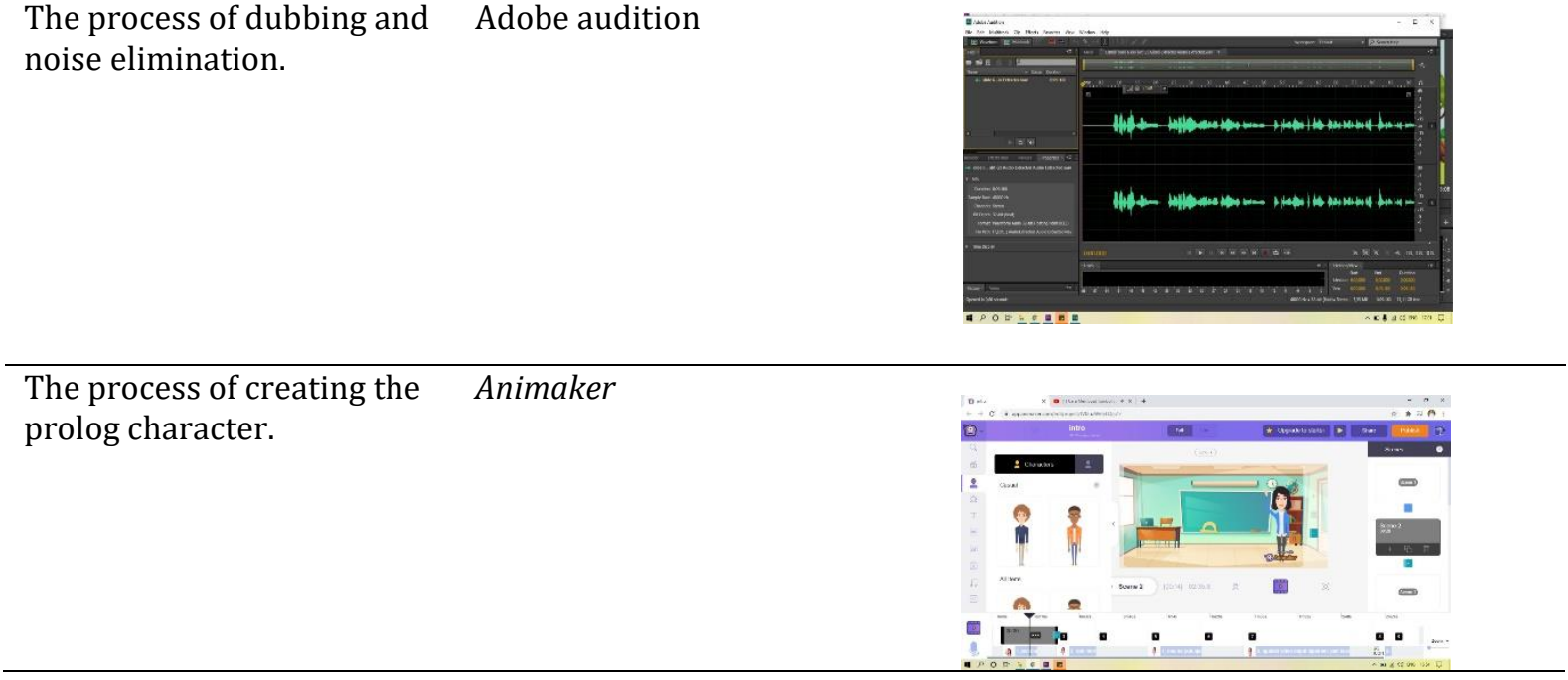

The development stage is carried out by starting to develop the media under the design that has been approved by the supervisors. The media is made as attractive as possible, consists of a cover, opening part, comic content, and closing part, which is shown via video in a 16: 9 ratio. As some see the results of digital comics media developed shown in Figure 1.
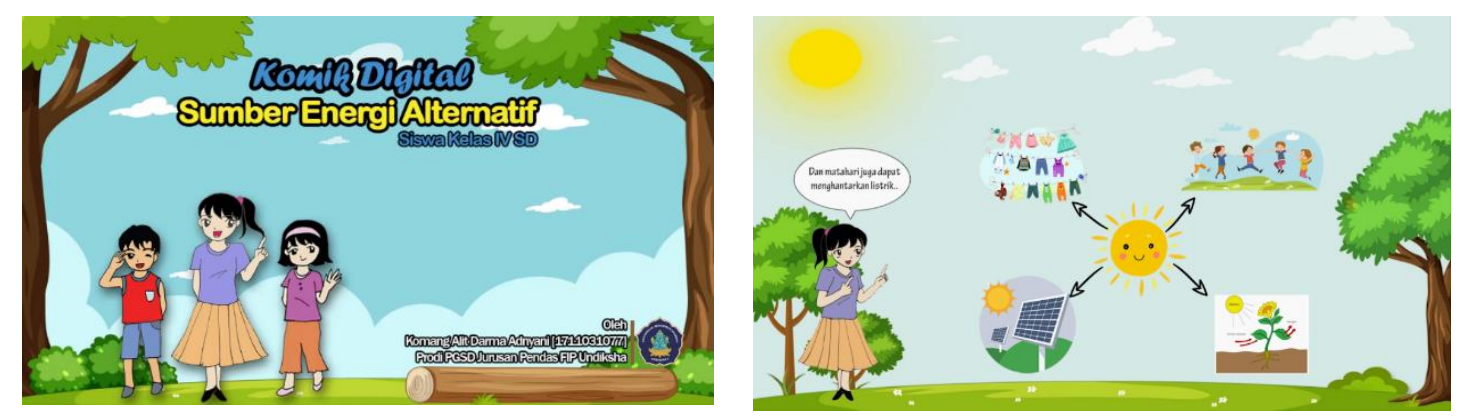
Figure 1. Digital Comic Media with The Topic of Alternative Energy Sources

After the media has been developed, the next step is to conduct media trials to determine the validity of the developed media. The results of the validity of digital comic media on the topic of alternative energy sources for fourth-grade elementary school students are presented in Table 6.

Table 7. Product Validity Test Results

\begin{tabular}{clcc}
\hline No & The subject of Media Trials & Validity Result (\%) & Classification \\
\hline 1. & Material Experts & $96 \%$ & Very Good \\
2. & Media Experts & $97 \%$ & Very Good \\
3. & Practitioners & $87 \%$ & Good \\
4. & Students & $94 \%$ & Very Good \\
\hline
\end{tabular}

The result of the validity test in Table 6 shows that the average percentage score of validity obtained from material experts is $96 \%$ with very good classification, the average percentage score of validity from media experts is $97 \%$ with very good classification, the average percentage score of practitioners is $87 \%$ with good classification, and the average percentage score obtained from fourthgrade elementary school students is $94 \%$ with very good classification. Judging from these results, each assessment from material experts, media experts, practitioners, and students obtained a percentage score in the range of $87 \%$ - 100\%. According to Table 5, the media developed are in very good classification. Therefore, digital comic media on the topic of alternative energy sources declared valid and suitable to use in learning.

\section{Discussion}

The development of digital comic media on the topic of alternative energy sources is suitable because it is following the ADDIE model procedure. The ADDIE model is a learning model that can be done to improve student learning outcomes (Cahyadi, 2019; Ulum et al., 2020). ADDIE has five stages consisting of analysis, design, development, implementation, and evaluation, but in this study implementation and evaluation stages cannot be implemented due to limited time, resources, and finances. Judging from the results of data analysis that have been converted into a five-scale achievement table, the media developed are in very good classification. Digital comic media is in very good classification because the aspects contained in digital comic media can support the learning process during online learning. Good learning media is supported based on visual, sound, and overall aspects (Apriansyah, 2020). The developed digital comic media has seven aspects, such as material/content, language/communication, presentation, sound and text, visuals, characterization, and overall appearance aspect. From the results of the material expert's assessment, the material/content aspects conveyed in the developed digital comic media are easy to understand, the level of material presented is following the characteristics of students, and clarity in providing examples according to the student's cognitive level. The language/communication aspects developed in this study used effective and efficient sentences, used clear punctuation and symbols, and used language that was easy to understand. Judging from the results of the media expert's assessment, the presentation aspects in the digital comic media developed have presented material coherently, the stories are presented are interesting, there is an integration of the material with the stories being told, and there are moving animations that can attract and improve student understanding. This is in line with the statement which states that attractive media can improve student understanding when used in a way that is following students' cognitive theory (Luthfi et al., 2020). Judging from the assessment of practitioners and students, the visual aspects of media illustrations with learning materials are appropriate, the sound and text aspects developed in this study have voices that can be heard, music that is under the story and student characteristics, the selection of text is appropriate and easy to read, and the background used looks attractive so that the appearance of the material and media as a whole is following the needs of the teacher, and digital comic media on the topic of alternative energy sources can be teaching materials for the teachers, Combining words, images, gestures, and audio provides an interesting experience for students (Fadly, 2019). Furthermore, a person can learn better by combining pictures and writing (Saputra \& Ciptadi, 2019).

Judging from the assessment of material experts, media experts, practitioners, and students as a whole, the aspects contained in the digital comic media development have very good classifications. These results are in line with research which shows that the results of the assessment of material experts, media experts, teacher assessments, and student questionnaires on the developed digital comic media get high scores with very good results so that it is suitable to be developed in learning (Mustikasari et al., 2020). 
Digital comics in learning can also raise student interest and participation in learning so that they are suitable to be used as learning media (Harismawan, 2020). Digital comics were chosen because they have advantages that are worthy of being used as a medium of learning, including: First, digital comics can place human faces or funny characters on certain subjects through written and visual interactions, thereby creating emotional relationships between students and various characters in the comic story. Second, digital comics can be applied to all subjects. Third, digital comics can attract students' attention regardless of age. Fourth, the content of digital comics is colorful using a writing style that is not as complicated as the book (Hao et al., 2020; Kanti et al., 2018). Unlike films and animations where the audience rate is adjusted to the media, comics are permanent where the rate is adjusted to the reader, and are intermediate. Comics can generate interest in reading and lead students to read discipline, especially those who don't like reading (Muyassaroh et al., 2019; Nguyen et al., 2018). In addition to that, another convenience of digital comics is the ease of access, because they can be read online via cellphone or tablet anytime and anywhere, can be stored easily, and can be sent to various media (Hadhinoto \& Oktavianti, 2020).

Regarding the discussion, digital comic media on the topic of alternative energy sources that being developed are believed to be suitable for use as a learning medium for fourth-grade elementary school students. In theory, elementary school students are at a concrete operational stage where children begin to function their minds to think rationally and objectively if assisted by concrete objects (Juwantara, 2019). This can be facilitated with developed media, because through digital comic media children can function their minds to think rationally, especially learning during the current pandemic. Learning during this pandemic, teachers and students cannot interact well but must communicate with a remote system, making it difficult for students to understand the material provided by the teacher, especially material on natural sciences subject. Most of the natural sciences subject topics are difficult for students to understand without an object that can be seen directly. The digital comic media developed are equipped with images that can help students understand the material. In addition, this media is also packaged in video form so that students can play it repeatedly if there is a material that has not been understood. Therefore, with this digital comic media, it is believed to be able to overcome problems in the education sector, in particular, it can add teaching materials for teachers, and can add learning materials for students so that students can easily understand the teaching material presented, and are motivated to take part in learning.

\section{Conclusion}

Referring to the results and discussion, it was concluded that digital comic media on the topic of alternative energy sources declared valid and suitable for use in learning, related to the problems encountered in the field, such as the lack of material on students' books and the lack of media in learning. In addition, the use of this media can increase students' interest in learning because the material in this media is packaged into a story, and this media also has different advantages from other media such as moving backgrounds and interesting characters that have never been encountered in previous media.

\section{References}

Ahmed, N., Ahmed, F., Jaffar, M., Shah, T., Khan, G., \& Bashir, S. (2021). Heliyon Teachers ' attitudes towards social media ( SM ) use in online learning amid the COVID-19 pandemic : the effects of SM use by teachers and religious scholars during physical distancing. Heliyon, 7(August 2020), e06781. https://doi.org/10.1016/j.heliyon.2021.e06781.

Akbar Saputra, F., \& Gembyeng Ciptadi, S. (2019). Komik Digital Sebagai Strategi Bisnis Media Online Olahraga: Studi Pada Gorilasport.Com. CoverAge: Journal of Strategic Communication. https://doi.org/10.35814/coverage.v9i2.1122.

Apriansyah, M. R. (2020). Pengembangan Media Pembelajaran Video Berbasis Animasi Mata Kuliah Ilmu Bahan Bangunan Di Program Studi Pendidikan Teknik Bangunan Fakultas Teknik Universitas Negeri Jakarta. Jurnal PenSil, 9(1), 9-18. https://doi.org/10.21009/jpensil.v9i1.12905.

Baharun, H. (2016). Pengembangan Media Pembelajaran Pai Berbasis Lingkungan Melalui Model ASSURE. Cendekia: Journal of Education and Society, 14(2), 231. https://doi.org/10.21154/cendekia.v14i2.610.

Cahyadi, R. A. H. (2019). Pengembangan Bahan Ajar Berbasis Addie Model. Halaqa: Islamic Education Journal, 3(1), 35. https://doi.org/10.21070/halaqa.v3i1.2124.

Daheri, M., Juliana, J., Deriwanto, D., \& Amda, A. D. (2020). Efektifitas WhatsApp sebagai Media Belajar Daring. Jurnal Basicedu, 4(4), 775-783. https://doi.org/10.31004/basicedu.v4i4.445. 
Dewi, W. A. F. (2020). Dampak COVID-19 terhadap Implementasi Pembelajaran Daring di Sekolah Dasar. EDUKATIF : Jurnal Ilmu Pendidikan. https://doi.org/10.31004/edukatif.v2i1.89.

Fadly, A. (2019). Perancangan Infografis Tutorial Comic Preparation untuk komikus pemula. Jadecs (Jurnal of Art, Design, Art Education \& Cultural Studies). https://doi.org/10.17977/um037v4i1p18-25.

Hadhinoto, P. S., \& Oktavianti, R. (2020). Komunikasi Persuasif Tentang Kesehatan Mental Melalui Komik Digital (Studi pada Akun Instagram @ @etualanganmenujusesuatu). Prologia, 3(2), 334. https://doi.org/10.24912/pr.v3i2.6355.

Hao, N. Z., Ikram, R. R. R., Md Bohari, N. M. A., Ngo, H. C., Salahuddin, L., \& Hassan, N. H. (2020). Comicmart: Digital comic aggregator platform with monetization schemes for local artists. International Journal of Advanced Trends in Computer Science and Engineering, 9(4), 6024-6030. https://doi.org/10.30534/ijatcse/2020/270942020.

Harahap, S. A., Dimyati, D., \& Purwanta, E. (2021). Problematika Pembelajaran Daring dan Luring Anak Usia Dini bagi Guru dan Orang tua di Masa Pandemi Covid 19. Jurnal Obsesi : Jurnal Pendidikan Anak Usia Dini, 5(2), 1825-1836. https://doi.org/10.31004/obsesi.v5i2.1013.

Harismawan, W. (2020). Penggunaan Komik Berbasis Web pada Mata Pelajaran Sejarah Siswa SMA. Indonesian Journal of Instructional Media and Model, 2(1), 40. https://doi.org/10.32585/ijimm.v2i1.634.

Hidayah, Y. F. (2017). Pengembangan Media Komik Digital Akuntansi Pada Materi The Development Of Accounting Digital Comic Media In The Material Of Writing Bank Reconciliation Report For Students Of Vocational Secondary School. 2, 239-250. https://doi.org/10.24832/jpnk.v2i2.588.

İlhan, G. O., Kaba, G., \& Sin, M. (2021). Usage of Digital Comics in Distance Learning During CoVID-19. International Journal on Social and Education Sciences. https://doi.org/10.46328/ijonses.106.

Juwantara, R. A. (2019). Analisis Teori Perkembangan Kognitif Piaget pada Tahap Anak Usia Operasional Konkret 7-12 Tahun dalam Pembelajaran Matematika. Al-Adzka: Jurnal Ilmiah Pendidikan Guru Madrasah Ibtidaiyah, 9(1), 27. https://doi.org/10.18592/aladzkapgmi.v9i1.3011.

Kanti, F. Y., Suyadi, B., \& Hartanto, W. (2018). Pengembangan Media Pembelajaran Komik Digital Pada Kompetensi Dasar Sistem Pembayaran Dan Alat Pembayaran Untuk Siswa Kelas X Ips Di Man 1 Jember. Jurnal Pendidikan Ekonomi: Jurnal Ilmiah Ilmu Pendidikan, Ilmu Ekonomi Dan Ilmu Sosial, 12(1), 135. https://doi.org/10.19184/jpe.v12i1.7642.

Luthfi, M. B., Rochmadi, S., Daryono, R. W., \& Saputra, R. P. S. (2020). The Development of Interactive Media Based on Video Animation in the Use of a Total Station for Measurement Stake out the Building. Budapest International Research and Critics in Linguistics and Education (BirLE) Journal, 3(4), 1773-1781. https://doi.org/10.33258/birle.v3i4.1345.

Mulenga, E. M. (2020). Is COVID-19 the Gateway for Digital Learning in Mathematics Education? 12(2). https://doi.org/https://doi.org/10.30935/cedtech/7949.

Mustikasari, L., Priscylio, G., Hartati, T., \& Sopandi, W. (2020). The development of digital comics on the ecosystem for thematic learning in elementary schools. Journal of Physics: Conference Series, 1469(1), 0-6. https://doi.org/10.1088/1742-6596/1469/1/012066.

Muyassaroh, M. N., Asib, A., \& Marmanto, S. (2019). The Teacher's Beliefs and Practices on the Use of Digital Comics in Teaching Writing: A qualitative case study. International Journal of Language Teaching and Education, 3(1), 45-60. https://doi.org/10.22437/ijolte.v3i1.6502.

Nguyen, N. Van, Rigaud, C., \& Burie, J. C. (2018). Digital comics image indexing based on deep learning. Journal of Imaging, 4(7). https://doi.org/10.3390/jimaging4070089.

Putria, H., Maula, L. H., \& Uswatun, D. A. (2020). Analisis Proses Pembelajaran dalam Jaringan (DARING) Masa Pandemi Covid- 19 Pada Guru Sekolah Dasar. Jurnal Basicedu, 4(4), 861-870. https://doi.org/10.31004/basicedu.v4i4.460.

Qazi, A., Qazi, J., Naseer, K., Zeeshan, M., Qazi, S., Abayomi-alli, O., Ahmad, I. S., Darwich, M., Talpur, A., Hardaker, G., Naseem, U., Yang, S., \& Haruna, K. (2021). Adaption of Distance Learning to Continue the Academic Year Amid COVID-19 Lockdown. Children And Youth Services Review, 106038. https://doi.org/10.1016/j.childyouth.2021.106038.

Rachman, F., \& Widowati, Y. S. (2018). Perancangan Media Pembelajaran Komik Digital Laboratorium Sejarah Rumah Arca Sebagai Upaya Pengenalan Sejarah Lokal. Jurnal Komunikasi Pendidikan, 1(2), 162-172. https://doi.org/10.32585/jkp.v1i2.28.

Rafique, G. M., Mahmood, K., Warraich, N. F., \& Rehman, S. U. (2021). Readiness for Online Learning during COVID-19 pandemic: A survey of Pakistani LIS students. Journal of Academic Librarianship, 47(3), 102346. https://doi.org/10.1016/j.acalib.2021.102346.

Ramadhan, B. S., \& Rasuardie, R. (2020). Kajian Industri Komik Daring Indonesia: Studi Komik Tahilalats. JSRW (Jurnal Senirupa Warna), 8(1), 2-18. https://doi.org/10.36806/jsrw.v8i1.80.

Ratnasari, D. T., \& Ginanjar, A. (2020). Pengembangan Komik Digital Sebagai Media Edukasi 
Penanggulangan Bencana Alam. Naturalistic: Jurnal Kajian Penelitian Pendidikan Dan Pembelajaran. https://doi.org/10.35568/naturalistic.v4i1.679.

Rifky, H. \&. (2017). Pengembangan media pembelajaran berbasis komik pada mata pelajaran ilmu pengetahuan sosial kelas IV MI Nurul Hidayah Roworejo Negerikaton Pesawaran. Jurnal Pendidikan Dan Pembelajaran Dasar, 4(1), 34-46.

Rigianti, H. A. (2020). Kendala Pembelajaran Daring Guru Sekolah Dasar Di Banjarnegara. Elementary School: Jurnal Pendidikan Dan Kembelajaran $-A n$. https://doi.org/10.31316/esjurnal.v7i2.768.

Rohmanurmeta, F. M., \& Dewi, C. (2019). Pengembangan Komik Digital Pelestarian Lingkungan Berbasis Nilai Karakter Religi Untuk Pembelajaran Tematik Pada Siswa Sekolah Dasar. Muaddib: Studi Kependidikan Dan Keislaman, 1(2), 100. https://doi.org/10.24269/muaddib.v1i2.1213.

Sadikin, A., \& Hamidah, A. (2020). Pembelajaran Daring di Tengah Wabah Covid-19. Biodik, 6(2), 109-119. https://doi.org/10.22437/bio.v6i2.9759.

Srivastava, S., Jacob, J., Charles, A. S., Daniel, P., Mathew, J. K., Shanthi, P., Devamani, K., Mahasampath, G., \& Rabi, S. (2021). Emergency remote learning in anatomy during the COVID-19 pandemic: A study evaluating academic factors contributing to anxiety among first-year medical students. Medical Journal Armed Forces India. https://doi.org/10.1016/j.mjafi.2020.12.012.

Sukmanasa, E., Windiyani, T., \& Novita, L. (2017). Pengembangan Media Pembelajaran Komik Digital Pada Mata Pelajaran Ilmu Pengetahuan Sosial Bagi Siswa Kelas V Sekolah Dasar Di Kota Bogor. Jurnal Pendidikan Sekolah Dasar, 3(2), 171. https://doi.org/10.30870/jpsd.v3i2.2138.

Tegeh, I. M., \& Kirna, I. M. (2013). Pengembangan bahan ajar metode penelitian pendidikan dengan addie model. Jurnal Ika, 11, 12-26.

Ulum, M. K., S, E. E., \& Ysh, A. S. (2020). Keefektifan Model Pembelajaran Addie Terhadap Hasil Belajar Matematika. Jurnal Penelitian Dan Pengembangan Pendidikan, 4(1), 98. https://doi.org/10.23887/jppp.v4i1.24774.

Wahyudin, A. Y., Jepri, D., Simamora, M. W., Pratiwi, I. W., \& Rina, A. (2020). Penggunaan Komik Digital Toondoo Dalam Pembelajaran Bahasa Inggris Tingkat Sekolah Menengah. Journal of Social Sciences and Technology for Community Service (JSSTCS). https://doi.org/10.33365/jta.v1i1.673.

Widjayanti, W. R., Masfingatin, T., \& Setyansah, R. K. (2018). Media Pembelajaran Interaktif Berbasis Animasi Pada Materi Statistika Untuk Siswa Kelas 7 Smp. Jurnal Pendidikan Matematika. https://doi.org/10.22342/jpm.13.1.6294.101-112. 